\title{
Allocation and funding of Speech and Language Therapy for children with Developmental Language Disorders across Europe and beyond
}

\author{
Hanne B. Søndergaard Knudsen ${ }^{\text {a, } * \text {, Niloufar Jalali-Moghadam }}{ }^{\text {b,c }}$, Silvia Nieva ${ }^{\text {d }}$, \\ Ewa Czaplewska ${ }^{\mathrm{e}}$, Marja Laasonen ${ }^{\mathrm{f}}$, Ellen Gerrits ${ }^{\mathrm{g}}$, Cristina McKean ${ }^{\mathrm{h}}$, James Law ${ }^{\mathrm{h}}$ \\ ${ }^{a}$ Center for Developmental \& Applied Psychological Science (CeDAPS), Aalborg University, Teglgårds Plads 1, 9000, Aalborg, Denmark \\ ${ }^{\mathrm{b}}$ Blekinge Center of Competence, Blekinge County Council, Sweden \\ ${ }^{\mathrm{c}}$ Department of Psychiatry, Østfold Hospital Trust, Moss, Norway \\ ${ }^{\mathrm{d}}$ Complutense University of Madrid, Spain \\ e Institute of Logopaedics, University of Gdansk, Poland \\ ${ }^{\mathrm{f}}$ Logopedics, School of Humanities, Philosophical Faculty, University of Eastern Finland; Department of Psychology and Logopedics, University of \\ Helsinki; Department of Phoniatrics, Helsinki University Hospital, Finland \\ ${ }^{\mathrm{g}} \mathrm{HU}$ University of Applied Sciences Utrecht and Utrecht University, the Netherlands \\ ${ }^{\mathrm{h}}$ Newcastle University, UK
}

\section{A R T I C L E I N F O}

Number of reviews completed is 2

\section{Keywords:}

Direct therapy

Indirect therapy

Mixed therapy

Funding policy

Implementation

Developmental Language Disorder

Speech and language therapy

\begin{abstract}
A B S T R A C T
Background: Children with Developmental Language Disorder (DLD) have a significant deficit in spoken language ability which affects their communication skills, education, mental health, employment and social inclusion.

Aim: The present study reports findings from a survey by EU network COST ACTION 1406 and aims to explore differences in service delivery and funding of SLT services for children with DLD across Europe and beyond.

Methods and procedures: The survey was completed by 5024 European professionals. COST countries were grouped into Nordic, Anglo-Saxon, Continental, Mediterranean, Central/Eastern and Non-European categories. The use of direct, indirect and mixed interventions, and their relationship to funding available (public, private or mixed) were considered for further analysis. Outcomes and results: The results revealed that for direct therapy, there were more cases than expected receiving private funding. For indirect therapy, fewer than expected received private and more than expected public funding. For mixed therapy, fewer cases than expected received private funding.

Conclusions and implications: The results implies that other factors than evidence-based practices, practitioners experience, and patient preferences, drive choices in therapy. More research is needed to gain a better understanding of factors affecting the choice of therapy.
\end{abstract}

\footnotetext{
* Corresponding author.

E-mail address: hannebsk@hum.aau.dk (H.B.S. Knudsen).
} 


\section{What this paper adds}

This paper provides analysis and discussion of a survey, developed by EU network COST ACTION 1406 on service delivery for children with Developmental Language Disorders (DLD). The paper discusses the results in relation to practices and funding within and between different EU and Non-EU countries.

\section{Introduction}

Children with language disorders raise particular concerns not only for their parents, but also for professionals who are involved in designing and delivering the most appropriate therapies.

In Europe, approximately 5.8 million $^{1}$ children and adolescents have Developmental Language Disorder (DLD) (Bishop, Snowling, Thompson, Greenhalgh, \& The CATALISE Consortium, 2016) which affects their communication skills and education outcomes; having long-term consequences for their mental health, employment and social inclusion (Law, Rush, Schoon, \& Parsons, 2009; Norbury et al., 2016). Across Europe, policies and practices vary widely as to how such difficulties are addressed (Law, McKean, Murphy, \& Thordardottir, 2019).

Policy makers and practitioners tasked with delivery of health and education services to children worldwide, seek to utilize resources to maximum benefit, invoking evidence-based policy and practice to justify their choices. The sparse existing evidence regarding the relative efficacy of differing service delivery choices in the field is mainly based on models of provision in the UK or USA (Cirrin et al., 2010; Ebbels, McCartney, Slonims, Dockrell, \& Norbury, 2019; McKean, Gerrits, Tulip, \& Tolonen, 2019; Schooling, Venediktov, \& Leech, 2010). However, in Law, McKean et al. (2019), one can find a comprehensive report of the tailored practices used in managing DLD, across European countries and beyond: work which emerged from an EU network COST ACTION 1406 examining intervention practices and evidence for children with DLD.

Building on the groundwork laid by Law, McKean et al. (2019), and survey data collected as part of the COST Action (see Forsythe, Murphy, Tulip, \& Law, 2021; Stankova et al., 2020), this study aims to explore differences in service delivery and funding of SLT services for children with DLD across six country categories: Continental, Anglo-Saxon; Nordic, Mediterranean, Central/Eastern and non-European. Specifically, we examine the use of direct intervention (delivered by a Speech and Language Therapist (SLT), indirect (by others under their guidance of an SLT) and mixed interventions, and their relationship to funding available (public, private or mixed).

\subsection{Evidence based practice}

According to the principles of evidence-based practice (EBP), health service delivery should be guided by three 'pillars': individual clinical expertise, best available evidence and the preference of a fully informed client (Law, Roulstone, \& Lindsay, 2015). Whilst the consideration of these three pillars is the ideal, other determining (mostly context-based and unacknowledged) factors have substantial influence in forming practices across countries. For example, policies regarding funding, prioritization of resources and resource allocation.

The state of the art is complex and is intertwined with both micro- (e.g., practitioners' decision-making preferences) and macrolevel (context-specific policies) variables. An understanding of how such context-specific factors may operate across countries may be disguised behind language barriers across countries (Amano, González-Varo, \& Sutherland, 2016). The question is, how the three pillars of EBP might feed through to decision making regarding direct, indirect and mixed models of intervention delivery.

\subsubsection{Individual clinical expertise}

Clinical expertise is central in the decisions as to which to offer. In educational and health systems, specialist practitioners are trained to diagnose and intervene with children with language disorders. In the main, these are Speech and Language Therapists/ pathologists (SLT hereafter), working in partnership with other professionals or family members to deliver interventions: partnerships which support generalization of skills to the 'real world' and maximize impact. As a result, service delivery to a child can be characterized as direct (delivered by an SLT), indirect (by one other than SLTs but under their guidance) and mixed (using both) (Law et al., 2002).

Taking a closer look at the descriptions of services reported across countries in Law, McKean et al. (2019), it is possible to identify that some countries of geographical proximity and similar social structures tend to share common preferences in therapy allocation policies. For example, in Norway, Sweden, Denmark and Finland (i.e. Nordic countries), both direct and indirect therapies were reported as preferred choices depending on the severity profile of DLD. Whereas, in countries in the Mediterranean region e.g., Italy, Portugal and Spain, sharing similarities regarding social welfare systems (Sapir, 2006), we find a larger variation across reports. In Italy, direct therapies were shown to be usually preferred for persistent and severe difficulties in children older than three years (De Cagno, Mollo, Citro, Roch, \& Marini, 2019); in Spain, the age of the child appeared to be an important factor in determining therapy models, i.e., the younger the child, the greater possibility of indirect therapy (Rodríguez-Ortiz, Acosta-Rodriguez, Nieva, \& Saldaña, 2019); while in Portugal most intervention is offered directly by SLTs (Castro \& Alves, 2019).

1 https://research.ncl.ac.uk/echo/. 


\subsubsection{Best available evidence}

There is evidence of positive effects of direct therapy delivered by an SLT for children with DLD (see e.g., Ebbels, 2014; Ebbels et al., 2017, Ebbels et al., 2019; Lowe, 2018; Wales, Skinner, \& Hayman, 2017). However, there has been a growing interest in indirect therapies (Mecrow, Beckwith, \& Klee, 2010). Especially, that there is variability in how parents accept professional authority (Morel, 2012). Indirect models leave more active role to parents and professionals who then are a guide rather than an authority. Models and practices of collaborative working amongst professionals through which indirect therapies can be delivered fall along a continuum of integration from a consultative approach at one end, where the SLT is in charge and delegates action to others, to a fully integrative/transdisciplinary approach at the other, where goals, methods of working and roles are negotiated and shared (Boon, Verhoef, O'Hara, \& Findlay, 2004; Dunst, Johanson, Trivette, \& Hamby, 1991). This transdisciplinary working brings benefits such as being user-friendly, economic and lightening family stress (King et al., 2009).

With appropriate levels of support and resources, such models can be effectively delivered by Speech and Language Therapy Assistants (Boyle, McCartney, O'Hare, \& Forbes, 2009), teachers (Pence, Justice, \& Wiggins, 2008), specialist teaching assistants (Mecrow et al., 2010) and mainstream classroom assistants (Bowyer-Crane et al., 2008) withstanding, collaboration and positive social relationships between those involved in policy and services for children with speech, language and communication needs bring benefits (McKean et al., 2017).

Interventions delivered through parents are widely used, particularly with pre-school children, with meta-analyses demonstrating their efficacy (Heidlage et al., 2019; Roberts \& Kaiser, 2011). Here, the models of working tend to involve parent training and coaching in responsive and contingent interaction and book-reading interventions. As in the case of interprofessional practice, these models are not universally effective (c.f. Wake et al., 2011) and the complexity and the skills required in developing parental engagement must not be underestimated (Klatte et al., 2020).

Although indirect therapy is shown to be effective, it is not always the first choice for professionals, and the choice for a certain service delivery model is influenced by multiple factors including the unique profile of the child, available financial and service provision resources, and available information for practitioners. The dominance of English as the language of publication for intervention research may also be barriers for implementation of new practices (Aboud \& Yousafzai, 2015; Forsythe et al., 2021; Guralnick, 2011; Pérez-Llantada, 2012).

Beyond Anglo-Saxon countries, in Central/Eastern European countries, such as Poland, schoolchildren with language disorders are treated in school or in psychological and pedagogical counselling centers by professionals (Poland. Ministry of National Education, 2017). Although the same regulation allows for the possibility of home therapy for preschool children, there is no mention of the advisability of indirect therapy (Czaplewska, Faściszewska, Kurowska, \& Smoczynska, 2019). While in Croatia, the most SLPs provide direct therapy (Kuvac Kraljevic, Matic, \& Pavicic Dokoza, 2020). In a recent study carried out in Lebanon, practices with children identified with a language difficulty in pre-school age more often take a direct therapy approach (22.61 \%) than indirect, involving teachers and parents (16.45 \%) (Kouba Hreich, Messarra, Martinez-Perez, Richa, \& Maillart, 2020).

\subsubsection{Preferences of the client}

EBP includes consideration of the views and preferences of the patient/family, and collaborative models can be highly valued by families. Bell, Corfield, Davies, and Richardson (2010) report an increase of $>50 \%$ in parent attendance to therapy sessions in a study on cost-efficiency of SLTs working in a paediatric service. However, disorder severity may influence parents' preferences (Watts Pappas, McAllister, \& McLeod, 2016). Indirect therapy provision may also be viewed with suspicion by parents and teachers as being cost-cutting measures rather than driven by any potential benefits for the child or family (Law et al., 2002).

It appears that different countries may currently be at different levels of implementing EBP in their social and educational services (Fixsen, Blase, Metz, \& Van Dyke, 2013). However, it is also undeniable that the nature of funding influences the choices which are available to a practitioner, particularly with respect to service delivery (dosage, location, agent of therapy etc.) (Law, Levickis et al., 2019; Law, McKean et al., 2019; Law, Roulstone, \& McCartney, 2019; McKean et al., 2019). As mentioned above, context-based factors may have substantial influence in forming practices across countries. For example, economic resources have been suggested as fourth 'hidden pillar' in EBP that influences clinical decisions (Law, 2019).

\subsection{Funding policies across countries}

The body of research regarding funding policies for DLD is very limited and so, research from other domains has been considered for the purpose of this study.

Resource allocation policies vary across countries; from those with a market-orientation (e.g., US) (Liu, 2003) to centrally planned health systems (e.g., in a number of Southeastern European countries) (Jakovljevic, 2013). Policies may technically benefit from a mixed pattern of funding allocation tools (Liu, 2003); and policy tools may vary substantially from one context to other. Obviously, healthcare services are designed with cost effectiveness in mind. Ensuring expenditure is fair i.e., making sure that the right services get to the right consumers and in the right place (Meekison, Mackenzie, \& Fraser, 1975); as well as directing resources toward the most cost-effective interventions are expected as government tasks. However, there is no documented literature examining a causal relation between government provision systems and cost-effectiveness (Liu, 2003).

To explore the influence of funding policy on decision making regarding direct or indirect therapy for children with DLD, we considered available taxonomies used in policy research to group countries with respect to their approach to welfare. In the present study, we basically applied the models advocated by Sapir (2006) using four European subgroups: Continental, Anglo-Saxon, Nordic and Mediterranean. However, a number of COST European countries, which were not entailed by Sapirs' model, were grouped based 
on their geographical proximity. Moreover, the Central/Eastern European group was considered as a fifth one, as the postsocialist welfare states were suggested being more profoundly different compared to the previous models in Europe (Beblavý, 2008). Notably, in Beblavý (2008), Central and Eastern countries were categorized into five groups, but for the purpose of the present study, these countries were merged into one group as the Central/Eastern European. Since COST Action hosted also a few non-European participant countries, a sixth group was considered to include these (see also Jalali-Moghadam et al., in preparation).

Along with macro-level inter-differences between country categories, there may also be differences within groups when it comes to funding policies allocated to therapies. Health systems are often considered as four main types: Social insurance (e.g. in Germany), National Health Service (e.g. in UK) National health insurance (e.g. Canada) and Private insurance (e.g. the U.S. system) (Frogner, Hussey, \& Anderson, 2011, p. 10). When it comes to provision of funding of intervention for DLD, there are variations, across Europe, e. g., in Poland, therapies were reported to be provided by public educational subsidies and to a large extent by private funds (Dziedzic, 2018).

In the present study, we also considered whether public, private or mixed models of funding affected service delivery decisions. The study arises from the work of European COST Action 1406: Enhancing children's oral language skills across Europe and beyond - a collaboration focusing on interventions for children with difficulties learning their first language. COST ${ }^{2}$ is a European Union Horizon 2020 funding mechanism which enables an international network of professionals to collaborate. The present study addresses three research questions:

1) Are there differences in the distribution of service delivery and funding of SLT services for children with DLD within Europe and beyond? We expected differences in the distribution of service delivery and funding types due to the different contexts in which children are receiving therapy e.g. school setting, clinic, private practice.

2) Is there a relationship between funding type, country category and service delivery? We expected that more private funding may be linked to more direct intervention as it may need to be more responsive to parental expectations and less flexible in terms of delivery location and distribution of effort across agencies.

3) Do funding and country category predict the practice model from which the child receives therapy?

\section{Method}

\subsection{Design}

The study is based on a survey on service delivery for children with Developmental Language Disorders (DLD), which was designed by members of COST Action IS1406 ${ }^{2}$.

Survey questionnaires were developed, checked with practitioners for meaning and accessibility, translated, back-translated and then formatted into language specific version of the survey questionnaire which was then entered into Survey Monkey ${ }^{\circledR}$ to produce an on-line survey and language specific links. The translations were all carried out by members of the COST Action who were fluent in their home languages and spoke English which was the designated language of the Action. The links were then distributed to practitioners online by professional bodies and national teams for each COST Action country in the appropriate language or languages. Participants also shared the questionnaire online which increased the distribution of the survey. Anyone could complete the survey if they had responsibility for managing the treatment of children with developmental language disorder. Online data collection was completed in 2017 by members of COST Action IS1406.

Participants answered closed and open-ended questions online to provide information about their management of children with DLD. Full details of the survey are provided in Law, McKean et al. (2019). The survey itself and the relevant accompanying documents are publicly available in the Newcastle University (UK) data repository ${ }^{3}$.

In addition, members of the Action have been involved in a series of separate analyses of the survey data with regard to the role of parents across the respondent countries (Law, Levickis et al., 2019), cultural and linguistic factors (Stankova et al., 2020) and choice of service delivery in different countries in relation to language profile of children with DLD (Jalali-Moghadam et al., in preparation).

The COST Action members were SLTs, linguists and psychologists, working with children with language impairments. The target countries comprised the 36 countries involved in the Action.

\subsection{Ethical statement}

Ethical approval for the survey and its dissemination was obtained from the University of Newcastle Research Ethics Committee on 18 January 2017 (Ref: 11532/2016). Respondents were invited to take part in the survey and consent was assumed by virtue of completion. With respect to respondent characteristics, only data regarding professional experience/training were collected. No names

\footnotetext{
${ }^{2}$ COST is an intergovernmental framework consisting of 36 Member Countries and a Cooperating State. Participating COST countries were: Albania, Austria, Belgium, Bosnia Herzegovina, Bulgaria, Croatia, Cyprus, Czech Rep, Denmark, Estonia, Finland, France, Germany, Greece, Hungary, Iceland, Ireland, Israel, Italy, Latvia, Lebanon, Lithuania, Luxembourg, Macedonia, Malta, Netherlands, Norway, Poland, Portugal, Romania, Serbia, Slovakia, Slovenia, South Africa, Spain, Sweden, Switzerland, Turkey, United Kingdom (see Law, J., McKean, C., Murphy, C.-A., \& Thordardottir, E. (2019)).

3 Available at: https://data.ncl.ac.uk/articles/COST_Action_IS1406_Practitioner_Survey/9802880.
} 
of respondents were collected, and the data were all anonymized in the analyses.

\title{
2.3. Participants
}

The survey yielded 6003 responses. Participants were excluded from further analysis, if they had only answered Section 1 with details about the respondent themselves $(N=979)$. The present sample consisted of a total of 5024 participants across 39 COST Action countries. Of the respondents, $95.6 \%$ were women. Distribution of ages were as follows: $26.6 \%, 20-30$ years-old, $29.1 \%$, 31-40 years old, $23.1 \%$, 41-50 years-old, $17.6 \%, 51-60$ years-old and $3.6 \%$ were more than 60 years-old. The majority ( $80 \%$ ) were SLTs, having bachelor (38.2 \%) or a master's degree (41.1\%). The average number of years' experience of working with children with DLD was 12.75 (SD =9.79). Most were monolingual (79.1\%), and $19.1 \%$ of the bilingual respondents spoke two languages at work.

\subsection{Instrument}

The survey had four Sections 1) background information about the professional who answered the survey, age, gender etc.; 2) questions on service delivery 3) theoretical considerations and 4) social and cultural contexts of intervention for children with DLD.

The respondent was asked to think of 'a typical child' case with language impairment from the usual caseload for whom the respondent had provided intervention in the last 2-3 months. The respondent was asked to answer with this particular child in mind. The present article is based on a combination of information from the following two questions (Fig. 1):

\subsection{Approach to analyses}

To maintain the required margin of confidence and error level, COST countries with less than 30 participants (Albania, Bosnia Herzegovina, Luxembourg, Macedonia, Malta and non-COST action countries), (see Law, Tulip \& Beckermann, 2019) were excluded $(N=94)$ from further analysis, resulting in a total number of 4930 participants. The remaining 34 survey-countries were grouped into the five European and one non-European categories. Continental: Austria, France, Germany, Belgium, Switzerland, Anglo-Saxon: United Kingdom, Ireland, Nordic: Norway, Sweden, Finland, Denmark, the Netherlands, Iceland, Mediterranean: Italy, Spain, Greece, Portugal, Cyprus, Central/Eastern European: Bulgaria, Romania, Slovakia, Slovenia, Czech Rep, Poland, Latvia, Estonia, Croatia, Hungary, Lithuania, Serbia, and Non-European countries: Turkey, Lebanon, Israel, South Africa.

For the analysis, the funding options were grouped into three categories: 1) Public: Government funded (health), Government funded (social services), Government funded (education), Charity, Health Insurance (funded), Practitioner is delivering free of charge (pro bono) and 2) Private: Family and Health insurance (private) or 3) Both (Public and Private).

\section{Results}

First, we explored the distribution of Type of Therapy and Type of Funding in the data. Table 1 presents the frequencies. As it can be seen from the Table 1, one participant could receive multiple types of therapies or funding, indicated by the total number exceeding the number of participants $(N=4930)$. For this reason, the variables were collapsed, with those 118 participants receiving only "other" funding excluded from the analyses. Type of Therapy was categorized as indirect, direct, or mixed. Type of Funding was categorized as private, public, or multiple. The final number of participants in the analyses was 4816. There were no missing values in the data.

The distribution of the categorical variables Type of Therapy and Type of Funding was inspected compared to even distribution using one-sample chi-square tests. For both the Type of Therapy and Type of Funding, the distribution to the categories was unequal (Therapy: $\chi 2(2)=3414.91, p<.001$; Funding: $\chi 2(2)=2449.63, p<.001)$. In Type of Therapy, direct therapy appeared to be more prevalent and indirect less prevalent than expected. In Type of Funding, public funding appeared to be more prevalent than expected

\author{
*2. For this particular child how is the intervention funded? (Please tick any or all that apply) \\ Government funded (health) \\ Government funded (social services) \\ Government funded (education) \\ Charity \\ Family \\ Health Insurance (funded) \\ Health insurance (private) \\ Practitioner is delivering free of charge (pro bono) \\ Other (please specify) \\ *3. For this particular child how is the intervention delivered? (Please tick any or all that apply) \\ Directly - face to face delivery of the intervention by you \\ Indirectly - other people deliver the intervention which you design and oversee
}

Section 2: Issues regarding intervention delivery, question 2 and 3, page 217

Fig. 1. COST Action IS(1406) (2017). Understanding language impairment across Europe and beyond. 
Table 1

Frequencies of Type of Therapy and Type of Funding.

\begin{tabular}{|c|c|c|c|c|}
\hline & & \multicolumn{3}{|c|}{ Type of Funding } \\
\hline & & $\begin{array}{l}\text { Public } \\
\text { Count }\end{array}$ & $\begin{array}{l}\text { Private } \\
\text { Count }\end{array}$ & $\begin{array}{l}\text { Both } \\
\text { Count }\end{array}$ \\
\hline \multirow[t]{3}{*}{ Type of Therapy } & Indirect & 174 & 18 & 21 \\
\hline & Direct & 2232 & 795 & 409 \\
\hline & Mixed & 801 & 197 & 169 \\
\hline
\end{tabular}

whereas private and receiving both types of funding less than prevalent expected (see Fig. 2).

Second, we analysed whether there were significant associations between Type of Therapy, Type of Funding, and Type of Country. The three-way-interaction between the variables could not be inspected because the requirements of hierarchical log linear analysis were not met regarding the expected count per cell. The significant two-way interactions were inspected with separate chi-square analyses for which the requirements for the expected counts per cell were met. For Type of Funding $\mathrm{x}$ Type of Therapy, the chi square test showed that there was a significant association $(\chi 2(4)=48.17, p<.001)$ and the size of the effect was small (Cramér's $\mathrm{V}=$ $.07, p<.001$ ). Standardized residuals (see Table 2) suggested that for the mixed Type of Therapy, there were more cases than expected receiving both Type of Funding and fewer cases than expected receiving private. For direct therapy, there were more cases than expected receiving private funding. The pattern was the opposite for indirect therapy where fewer than expected received private and more than expected public funding.

For Type of Funding $x$ Type of Country, the chi-square test showed that there was a significant association $(\chi 2(10)=1071.42, p<$ .001 ) and the size of the effect was medium (Cramér's $V=.33, p<.001$ ). Standardized residuals suggested that almost all the cells contributed significantly to the overall chi-square (see Table 3). For the Continental Type of Country, more than expected received public or both funding and fewer than expected private. In the Anglo-Saxon and Nordic countries, more than expected received public funding and fewer than expected private or both. In the Mediterranean and NonEuropean countries, more than expected received private funding and fewer than expected public. In the Central European category, fewer than expected received private funding. The analyses for Type of Country x Type of Therapy are presented elsewhere (Jalali-Moghadam et al., in preparation).

Lastly, we wanted to know whether the funding and country category predict therapy type. A hierarchical multinomial regression was conducted between the categorical predictors of Type of Funding (public: yes/no, private: yes/no) and Type of Country and the Type of Therapy as the outcome variable with mixed as baseline category. Entering the main effects and the interaction to the model improved its fit $(\chi 2(24)=723.32, p<.001)$ resulting in a good fit (Pearson $(\chi 2(10)=16.09, p=.097)$. The prediction of Therapy Type by Private Funding was significant $(\chi 2(2)=32.78, p<.001)$ as well as the interaction between Public Funding and Type of Country $\left(\chi^{2}(10)=23.61, p=.009\right)$. These results indicate that country and whether the child received public funding did not predict therapy type but, instead, therapy type is predicted by whether the child received private funding and whether the child received public funding in a certain country.

\section{Discussion}

The present study aimed to explore how services for children with DLD are organised and delivered within Europe and beyond. The results of the survey revealed that the predominant choice of SLT service was direct therapy. SLT services were most often paid by public funding and less frequently by private funding or a mix of both types of funding. The service delivery model was predicted by whether the child received private funding and whether the child received public funding in a certain country.
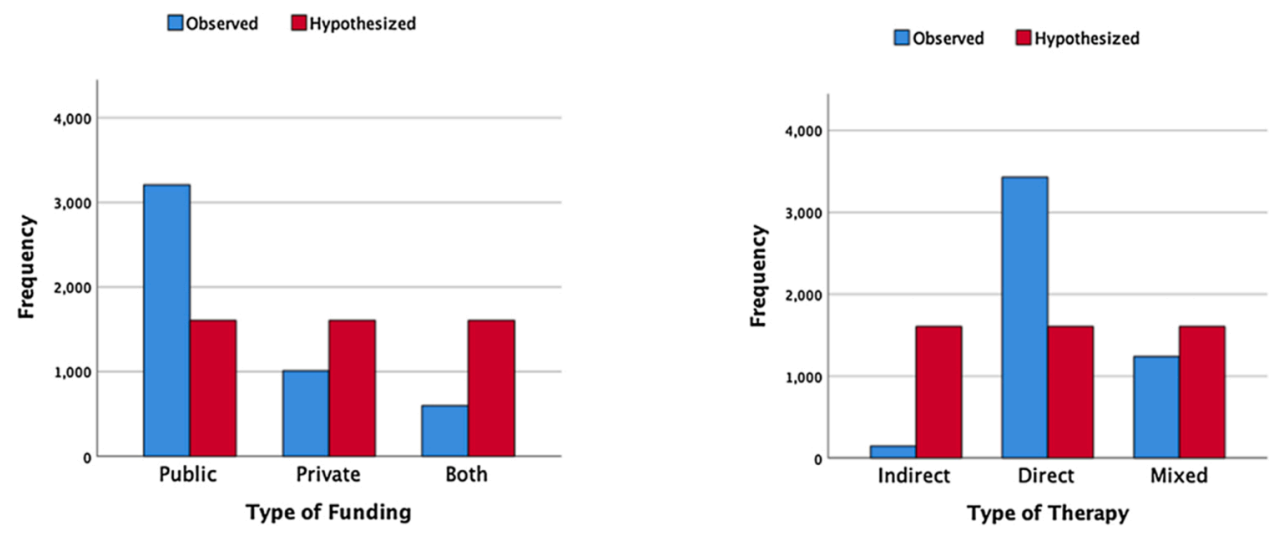

Fig. 2. Type of Funding and Type of Therapy. 
Table 2

Type of Funding * Type of Therapy Crosstabulation.

\begin{tabular}{|c|c|c|c|c|c|c|}
\hline & & & \multicolumn{3}{|c|}{ Type of Therapy } & \multirow[b]{2}{*}{ Total } \\
\hline & & & Indirect & Direct & Mixed & \\
\hline \multirow[t]{9}{*}{ Type of Funding } & Public & Count & $174_{a}$ & $2232_{\mathrm{b}}$ & $801_{b}$ & 3207 \\
\hline & & Expected Count & 141.8 & 2288.1 & 777.1 & 3207.0 \\
\hline & & Standardized Residual & 2.7 & -1.2 & .9 & \\
\hline & Private & Count & $18_{\mathrm{a}}$ & $795_{b}$ & $197_{\mathrm{c}}$ & 1010 \\
\hline & & Expected Count & 44.7 & 720.6 & 244.7 & 1010.0 \\
\hline & & Standardized Residual & -4.0 & 2.8 & -3.1 & \\
\hline & Both & Count & $21_{\mathrm{a}}$ & $409_{a}$ & $169_{a}$ & 599 \\
\hline & & Expected Count & 26.5 & 427.4 & 145.1 & 599.0 \\
\hline & & Standardized Residual & -1.1 & -.9 & 2.0 & \\
\hline \multirow[t]{2}{*}{ Total } & & Count & 213 & 3436 & 1167 & 4816 \\
\hline & & Expected Count & 213.0 & 3436.0 & 1167.0 & 4816.0 \\
\hline
\end{tabular}

Each subscript letter denotes a subset of Type of Therapy categories whose column proportions do not differ significantly from each other at the .05 level.

Table 3

Type of Funding * Type of Country Crosstabulation.

\begin{tabular}{|c|c|c|c|c|c|c|c|c|c|}
\hline & & & \multicolumn{7}{|c|}{ Type of Country } \\
\hline & & & Continental & $\begin{array}{l}\text { Anglo- } \\
\text { Saxon }\end{array}$ & Nordic & Mediterranean & $\begin{array}{l}\text { Central/Eastern } \\
\text { European }\end{array}$ & $\begin{array}{l}\text { Non- } \\
\text { European }\end{array}$ & Total \\
\hline \multirow{9}{*}{$\begin{array}{l}\text { Type of } \\
\text { Funding }\end{array}$} & Public & Count & $989_{a}$ & $205_{b}$ & $453_{b}$ & $518_{c}$ & $964_{d}$ & $78_{e}$ & 3207 \\
\hline & & Expected Count & 867.0 & 150.5 & 323.0 & 792.4 & 912.3 & 161.8 & 3207.0 \\
\hline & & $\begin{array}{l}\text { Standardized } \\
\text { Residual }\end{array}$ & 4.1 & 4.4 & 7.2 & -9.7 & 1.7 & -6.6 & \\
\hline & Private & Count & $70_{\mathrm{a}}$ & $18 \mathrm{a}$ & $16_{a}$ & $538_{b}$ & $228_{c}$ & $140_{\mathrm{d}}$ & 1010 \\
\hline & & Expected Count & 273.1 & 47.4 & 101.7 & 249.6 & 287.3 & 51.0 & 1010.0 \\
\hline & & $\begin{array}{l}\text { Standardized } \\
\text { Residual }\end{array}$ & -12.3 & -4.3 & -8.5 & 18.3 & -3.5 & 12.5 & \\
\hline & Both & Count & $243_{\mathrm{a}}$ & $3_{\mathrm{b}}$ & $16_{\mathrm{b}}$ & $134_{c}$ & $178_{\mathrm{c}}$ & $25_{c}$ & 599 \\
\hline & & Expected Count & 161.9 & 28.1 & 60.3 & 148.0 & 170.4 & 30.2 & 599.0 \\
\hline & & $\begin{array}{l}\text { Standardized } \\
\text { Residual }\end{array}$ & 6.4 & -4.7 & -5.7 & -1.2 & 0.6 & -1.0 & \\
\hline \multirow[t]{2}{*}{ Total } & & Count & 1302 & 226 & 485 & 1190 & 1370 & 243 & 4816 \\
\hline & & Expected Count & 1302.0 & 226.0 & 485.0 & 1190.0 & 1370.0 & 243.0 & 4816.0 \\
\hline
\end{tabular}

Each subscript letter denotes a subset of Type of Country categories whose column proportions do not differ significantly from each other at the .05 level.

\subsection{Service delivery}

Our findings show that direct therapy was the most widely applied model. Ideally, choices of therapy should be based on needs of the child and the family with variation in types of therapy, such as indirect, direct or mixed. The traditional view of child-directed intervention comes from a medical model and so treatment focuses on the individual's impairment to correct poor functioning and then it is planned and delivered by an expert. More social models of disability (see ICF, WHO, 2001) with their focus on functioning and the influence of the individual's environment necessary imply the need for 'indirect' models of intervention. Such radical changes in perspective not only require institutional support but a substantive cultural shift, and different countries are at different starting points in this journey (Dunst \& Trivette, 2009).

Fixsen et al. (2013) suggest a number of stages of implementation for changes (exploration, installation, initial as well as full implementation). Some countries in our survey may be at the early stages of implementation for an indirect or mixed service delivery model. For example, Portugal and Spain, two of the countries within the Mediterranean group, are currently in the process of a change to an indirect therapy model. Serrano, Mas, and Cañadas (2016) highlight that professionals in Portugal aim to implement indirect models, but their reach has not yet been measured. In Spain, professionals identify the need for further training and resources and the profession is highly dependent on the influence of the SLTs' professional associations (García-Grau, Martínez-Rico, McWilliam, \& Grau, 2021).

In some countries, language support is provided in schools; e.g. United Kingdom, Croatia, Hungary, the Netherlands, Denmark, Norway, Sweden, while in many others mostly in private clinical settings; e.g. France, and Italy. Indirect services are used less frequently although Nordic and Anglo-Saxon countries share the widespread use of parent programs (e.g., the Hanen program) and deliver training/coaching to teachers (Law, McKean et al., 2019, part II, National Vignettes).

In many cases, the Anglo-Saxon countries, have policies that recommend practitioners working with parents in a family centered 
approach (Frizelle, O'Toole, Lyons, Tangney, \& Murphy, 2019, for Ireland, and Law, Roulstone et al., 2019 for UK). Similar policies may provide guidance sessions where schoolteachers could be instructed by specialized DLD teachers in inclusive schools. Notably, in the Nordic countries, there is a long history of specialist pedagogical practices (Jensen de López \& Knudsen, 2019); therefore, teachers have been empowered in learning and delivering effective indirect interventions in schools. Furthermore, parents could more readily be partners in intervention processes thanks to generous social policy e.g., with respect to parental leave (e.g. for Denmark, Ministry of Employment, 2021). It might be the case that in some countries it would be possible to use the current legislation that allows home therapy (e.g. for Poland, Czaplewska et al., 2019), but it may be necessary to provide EBP that would be acceptable to practitioners.

\subsection{Funding}

Analysis in the present study demonstrated that for mixed therapy, there were more cases than expected receiving both type of funding and fewer cases than expected receiving private. For direct therapy, there were more cases than expected receiving private funding. The pattern was the opposite for indirect therapy where fewer than expected received private and more than expected public funding.

The abovementioned interventions, predominantly publicly funded, indirect or mixed therapy types, perhaps provide greater flexibility to share the work involved in supporting children's development across agencies than those where billing and commissioning of services like direct therapy that are very closely linked to the hours of therapy received by a child.

In other countries, such as Romania, the general population may be unaware of the availability of SLT services (Zegan, Totolan, \& Ene, 2019) whilst in others such as Turkey the small numbers of practitioners may lead them to work in private practice (Topbas, Bulut, \& Gunhan, 2019). In these cases, direct therapy, being more "expert" focused, could be more likely to be demanded (e.g., De Cagno et al., 2019 for Italy and Rodríguez-Ortiz et al., 2019 for Spain).

In some Central-Eastern and Non-European countries, such as Bulgaria, South-Africa or Lebanon, non-profit external organizations usually provide support for treatment services (Dionissieva, Stankova, \& Boyadzhieva-Deleva, 2019; Messarra \& Kouba Hreich, 2019; Oosthuizen \& Southwood, 2019). In Poland, parents report a desire for their child to participate in many different forms of therapy, such as auditory or sensory integration training. However, they do not report the need to be instructed and provided by speech therapists on how to conduct therapy with their own child (Dziedzic, 2018).

\subsection{Funding, agency and society structure}

In the present study, we investigated a possible relationship between funding type, country category and service delivery. For the Continental category, public or both funding appeared to be most likely. In the Anglo-Saxon and Nordic countries public funding was most likely, and in the Mediterranean and NonEuropean countries private funding was most likely. In the Central European category private funding was less likely.

Although SLTs may be considered as decision-makers in shaping therapy models, countries' policies may act as structural barriers and have negative influence on developing appropriate therapies for DLD in many European countries. This raises an issue of agency versus structure, and some structural barriers for implementation of different service models for children with DLD may have their origin in governmental policies.

The National Vignettes published by this COST action provide additional information about funding across the included country categories: Continental countries: insurance companies, refunded by government public health; Anglo-Saxon countries: national centered funding management; Nordic countries: public health model (refunded or covered by health insurance), with increasing private practice. Mediterranean countries: services covered by social security or health insurance with cuts on coverage, there is also private practice; Central/Eastern European countries: more variability: services led by external organizations (such as UNICEF), public model (from health, education or social services), only private model or mixed model, and, Non- European countries: public, private or mixed models and, also non-governmental organizations support (see Law, McKean et al., 2019 part II, National Vignettes).

\subsection{Evidence based practice and implications for practice and policy}

The finding, that therapy type was predicted by whether it was privately funded and whether it was publicly funding in a certain country, implies that other factors than evidence, practitioners experience, and patient preferences (EBP) drive choices in therapy. Although EBP may be a desired model among policy makers, interventions with strong evidence are often not applied by practitioners (Law et al., 2015). The reasons for choosing non-evidence-based interventions may be due to lack of adequate evidence (Cirrin et al., 2010; Ebbels et al., 2019; Schooling et al., 2010), acceptance of 'custom and practice' or lack of access to up-to-date literature.

Furthermore, the dominance of English as the language of publication for intervention research and the dominance of subscription only journal publications are significant barriers to access to many practitioners around the world (Aboud \& Yousafzai, 2015; Forsythe et al., 2021; Guralnick, 2011; Pérez-Llantada, 2012). In the study of ninety-nine practicing speech-language therapists from 13 countries, Jordaan (2008) revealed that the majority $(74 \%, n=73)$ of them were monolingual. In addition to the results obtained by O'Connor and Pettigrew (2009) where the most significant barrier influencing EBP implementation "was reported to be a lack of time to read research (71.9\%)“ (p. 1018), it seems that the dominance of English in the scientific literature may be an additional obstacle with access to up-to-date professional information.

Likewise, researchers frequently fail to convert research findings into methods and resources that can be readily understood and translated into clinical effectiveness (Cook, Cook, \& Landrum, 2013; Singer, Agran, \& Spooner, 2017). In addition, implementing a 
different type of therapy requires behavior change of professionals. To change habits of professionals, an implementation plan with behavioral change techniques is needed, more than just translating evidence or a publication in a professional journal (Michie, van Stralen, \& West, 2011).

In different cultures, clients' satisfaction and progress can be expressed in different ways more or less accessible to the professionals to evaluate the positive effect of a change of practices. To change functioning, planned and delivered intervention by an expert, it needs not only institutional support but a change of mentality (Dunst \& Trivette, 2009), and if also e.g. mixed or indirect therapy is to be an option, countries need to invest culturally and financially in implementation.

\subsection{Methodological limitations}

To interpret the findings of the present study, one must consider the wording of the questionnaire. We asked practitioners to reflect on a child they had worked with in the past three months and who was their typical case. This may have biased respondents to think about a child they were more actively involved in and therefore towards direct models of intervention.

\subsection{Conclusion}

The present study shows that direct therapy was the approach to intervention with children with DLD which was the most widely applied model in most countries. Services were most often financed by public funding. Furthermore, the interaction between country category and funding suggests that it is not simply the type of funding which matters but also the health, educational and care context within which the therapy is delivered. Financial models of health care seem to have a direct influence on individual intervention choice in some countries which may go beyond external published evidence. It is important that researchers pay attention to developments both evidence-based practice and implementation science in order to provide a basis for practitioners to intervene, based on individual clinical expertise, best available evidence and the preference of a fully informed client.

\section{Data availability}

Available at: https://data.ncl.ac.uk/articles/COST_Action_IS1406_Practitioner_Survey/9802880.

\section{CRediT authorship contribution statement}

Hanne B. Søndergaard Knudsen: Conceptualization, Methodology, Investigation, Resources, Writing - review \& editing, Project administration, Formal analysis. Niloufar Jalali-Moghadam: Conceptualization, Methodology, Investigation, Resources, Writing review \& editing, Project administration. Silvia Nieva: Conceptualization, Methodology, Investigation, Resources, Writing - review \& editing, Project administration. Ewa Czaplewska: Conceptualization, Methodology, Investigation, Resources, Writing - review \& editing, Project administration. Marja Laasonen: Formal analysis, Methodology. Ellen Gerrits: Conceptualization, Methodology, Investigation, Resources, Writing - review \& editing, Project administration, Funding acquisition. Cristina McKean: Conceptualization, Methodology, Investigation, Resources, Writing - review \& editing, Project administration, Funding acquisition. James Law: Conceptualization, Methodology, Investigation, Resources, Writing - review \& editing, Project administration, Data curation, Funding acquisition.

\section{Acknowledgements}

The data for this study were derived from the Practitioner Survey which was part of the work of Cost Action 1406 entitled: Enhancing children's oral language skills across Europe and beyond, a collaboration focusing on interventions for children with difficulties learning their first language. The Cost Action was funded by the European Union. We are grateful to the over a hundred members of the Action who contributed to the development of the questionnaire and, of course, to those who completed it.

\section{References}

Aboud, F. E., \& Yousafzai, A. K. (2015). Global health and development in early childhood. Annual Review of Psychology, 66, 433-457. https://doi.org/10.1146/ annurev-psych-010814-015128

Amano, T., González-Varo, J. P., \& Sutherland, W. J. (2016). Languages are still a major barrier to global science. PLoS Biology, 14(12). https://doi.org/10.1371/ journal.pbio.2000933. Article e2000933.

Beblavý, M. (2008). New welfare state models based on the new member states' experience?. Available at SSRN: https://ssrn.com/abstract=2403764 or https://doi.org/ $10.2139 /$ ssrn. 2403764 .

Bell, A., Corfield, M., Davies, J., \& Richardson, N. (2010). Collaborative transdisciplinary intervention in early years - Putting theory into practice. Child: Care, Health and Development, 36(1), 142-148. https://doi.org/10.1111/j.1365-2214.2009.01027.x

Bishop, D. V. M., Snowling, M. J., Thompson, P. A., Greenhalgh, T., \& The CATALISE Consortium. (2016). CATALISE: A multinational and multidisciplinary Delphi consensus study. Identifying language impairments in children. PloS One, 11(7). https://doi.org/10.1371/journal.pone.0158753

Boon, H., Verhoef, M., O'Hara, D., \& Findlay, B. (2004). From parallel practice to integrative health care: A conceptual framework. BMC Health Services Research, 4(1), 15. https://doi.org/10.1186/1472-6963-4-15

Bowyer-Crane, C., Snowling, M. J., Duff, F. J., Fieldsend, E., Carroll, J. M., Miles, J., ... Hulme, C. (2008). Improving early language and literacy skills: Differential effects of an oral language versus a phonology with reading intervention. Journal of Child Psychology and Psychiatry, 49(4), 422-432. https://doi.org/10.1111/ j.1469-7610.2007.01849.x. Epub 2007 Dec 11. PMID: 18081756. 
Boyle, J. M., McCartney, E., O'Hare, A., \& Forbes, J. (2009). Direct versus indirect and individual versus group modes of language therapy for children with primary language impairment: Principal outcomes from a randomized controlled trial and economic evaluation. International Journal of Language \& Communication Disorders, 44(6), 826-846. https://doi.org/10.1080/13682820802371848

Castro, A., \& Alves, D. C. (2019). National Vignettes: Portugal. In J. Law, C. McKean, C. A. Murphy, \& E. Thordardottir (Eds.), Managing children with developmental language disorder: Theory and practice across Europe and beyond (1st ed., pp. 374-386). London: Routledge. https://doi.org/10.4324/9780429455308.

Cirrin, F. M., Schooling, T. L., Nelson, N. W., Diehl, S. F., Flynn, P. F., Staskowsky, M., ... Zoann Torrey, T. (2010). Evidence-based systematic review: Effects of different service delivery models on communication outcomes for elementary school-Age children. Language, Speech, and Hearing Services in Schools, 41, $233-264$. https://doi.org/10.1044/0161-1461(2009/08-0128

Cook, B. G., Cook, L., \& Landrum, T. J. (2013). Moving research into practice: Can we make dissemination stick? Exceptional Children, 79(2), 163-180. https://doi. org/10.1177/001440291307900203

COST Action IS1406. (2017). Understanding language impairment across Europe and beyond. Retrieved April 10th, 2021 from: https://data.ncl.ac.uk/articles/COST_ Action_IS1406_Practitioner_Survey/9802880.

Czaplewska, E., Faściszewska, M., Kurowska, M., \& Smoczynska, M. (2019). National Vignettes: Poland. In J. Law, C. McKean, C.-A. Murphy, \& E. Thordardottir (Eds.), Managing children with developmental language disorder. Theory and practice across Europe and beyond (1st ed., pp. 363-373). London: Routledge. https://doi.org/ $10.4324 / 9780429455308$.

De Cagno, A. G., Mollo, F., Citro, R., Roch, M., \& Marini, A. (2019). National Vignettes: Italy. In J. Law, C. McKean, C. A. Murphy, \& E. Thordardottir (Eds.), Managing children with developmental language disorder: Theory and practice across Europe and beyond (1st ed., pp. 295-301). London: Routledge. https://doi.org/10.4324/ 9780429455308.

Dionissieva, K., Stankova, M., \& Boyadzhieva-Deleva, E. (2019). National Vignettes: Bulgaria (2019). In J. Law, C. McKean, C. A. Murphy, \& E. Thordardottir (Eds.), Managing children with developmental language disorder: Theory and practice across Europe and beyond (1st ed., pp. 158-168). London: Routledge. https://doi.org/ 10.4324/9780429455308.

Dunst, C. J., \& Trivette, C. M. (2009). Using research evidence to inform and evaluate early childhood intervention practices. Topics in Early Childhood Special Education, 29(1), 40-52. https://doi.org/10.1177/0271121408329227

Dunst, C. J., Johanson, C., Trivette, C. M., \& Hamby, D. (1991). Family-oriented early intervention policies and practices: Family-centered or not? Exceptional Children, 58(2), 115-126. https://doi.org/10.1177/001440299105800203

Dziedzic, M. (2018). Raport z badania ankietowego Formy terapii dzieci z afazja rozwojowa [Online]. Available at http://www.rozkodujmyafazje.pl/wp-content/uploads/ 2018/04/Raport-z-badania-ankietowego.pdf (Accessed 13 January 2021).

Ebbels, S. (2014). Effectiveness of intervention for grammar in school-aged children with primary language impairments: A review of the evidence. Child Language Teaching and Therapy, 30(1), 7-40. https://doi.org/10.1177/0265659013512321

Ebbels, S. H., Wright, L., Brockbank, S., Godfrey, C., Harris, C., Leniston, H., ... Marić, N. (2017). Effectiveness of 1:1 speech and language therapy for older children with (developmental) language disorder. International journal of language \& communication disorders, 52(4), 528-539. https://doi.org/10.1111/1460-6984.12297

Ebbels, S. H., McCartney, E., Slonims, V., Dockrell, J. E., \& Norbury, C. F. (2019). Evidence-based pathways to intervention for children with language disorders. International Journal of Language \& Communication Disorders, 54(1), 3-19. https://doi.org/10.1111/1460-6984.12387

Fixsen, D., Blase, K., Metz, A., \& Van Dyke, M. (2013). Statewide implementation of evidence-based programs. Exceptional Children, 79(3), 213-230. https:/doi.org/ 10.1177/001440291307900206

Forsythe, R., Murphy, C.-A., Tulip, J., \& Law, J. (2021). Why clinicians choose their language intervention approach: An international perspective on intervention for children with developmental language disorder. Folia Phoniatrica et Logopaedica: Official Organ of the International Association of Logopedics and Phoniatrics (IALP). https://doi.org/10.1159/000513242

Frizelle, P., O'Toole, C., Lyons, R., Tangney, A., \& Murphy, C. A. (2019). National Vignettes: Ireland (2019). In J. Law, C. McKean, C. A. Murphy, \& E. Thordardottir (Eds.), Managing children with developmental language disorder: Theory and practice across Europe and beyond (1st ed., pp. 272-284). London: Routledge. https://doi. org/10.4324/9780429455308.

Frogner, B. K., Hussey, P. S., \& Anderson, G. F. (2011). Health systems in industrialized countries. In S. Glied, \& P. C. Smith (Eds.), The Oxford handbook of health economics. https://doi.org/10.1093/oxfordhb/9780199238828.001.0001

García-Grau, P., Martínez-Rico, G., McWilliam, R. A., \& Grau, D. (2021). Early Intervention and Family-Centeredness in Spain: Description and Profile of Professional Practices. Topics in Early Childhood Special Education, 41(2), 160-172. https://doi.org/10.1177/0271121419846332

Guralnick, M. J. (2011). Why early intervention works: A systems perspective. Infants and Young Children, 24(1), 6-28. https://doi.org/10.1097/ IYC.0b013e3182002cfe

Heidlage, J. K., Cunningham, J. E., Kaiser, A. P., Trivette, C. M., Barton, E. E., Frey, J. R., ... Roberts, M. Y. (2019). The effects of parent-implemented language interventions on child linguistic outcomes: A meta-analysis. Early Childhood Research Quarterly, 50(Part 1), 6-23. https://doi.org/10.1016/j.ecresq.2018.12.006

Jakovljevic, M. B. (2013). Resource allocation strategies in Southeastern European health policy. The European Journal of Health Economics, 14, 153-159. https://doi. org/10.1007/s10198-012-0439-y

Jalali-Moghadam, N., Knudsen, H.B.S., Czaplewska, E., Nieva, S., Laasonen, M., Gerrits, E., McKean, C., Law, J. (In preparation). International differences in the relationship between direct or indirect therapy and language profiles in children with Developmental Language Disorder (DLD).

Jensen de López, K., \& Knudsen, H. B. S. (2019). National Vignettes: Denmark. In J. Law, C. McKean, C.-A. Murphy, \& E. Thordardottir (Eds.), Managing children with developmental language disorder: Theory and practice across Europe and beyond (1st edition, pp. 189-202). London: Routledge. https://doi.org/10.4324/ 9780429455308.

Jordaan, H. (2008). Clinical intervention for bilingual children: An international survey. Folia Phoniatrica et Logopaedica, 60(2), 97-105. https://doi.org/10.1159/ 000114652

King, G., Strachan, D., Tucker, M., Duwyn, B., Desserud, S., \& Shillington, M. (2009). The application of a transdisciplinary model for early intervention services. Infants and Young Children, 22(3), 211-223. https://doi.org/10.1097/IYC.0b013e3181abe1c3

Klatte, I. S., Lyons, R., Davies, K., Harding, S., Marshall, J., McKean, C., \& Roulstone, S. (2020). Collaboration between parents and SLTs produces optimal outcomes for children attending speech and language therapy: Gathering the evidence. International Journal of Language \& Communication Disorders, 55(4), 618-628. https://doi.org/10.1111/1460-6984.12538

Kouba Hreich, E. K., Messarra, C. M., Martinez-Perez, T., Richa, S., \& Maillart, C. (2020). Supporting language development in Lebanese preschools: SLT and pre-KT practice and perception of roles. International Journal of Language \& Communication Disorders, 55(6), 988-1004. https://doi.org/10.1111/1460-6984.12576

Kuvac Kraljevic, J., Matic, A., \& Pavicic Dokoza, K. (2020). Telepractice as a Reaction to the COVID-19 Crisis: Insights from Croatian SLP Settings. International Journal of Telerehabilitation, 12(2), 93-104. https://doi.org/10.5195/ijt.2020.6325

Law, J. (2019). Evidence-based practice and its application to developmental language disorders. In J. Law, C. McKean, C.-A. Murphy, \& E. Thordardottir (Eds.), Managing children with developmental language disorder: Theory and practice across Europe and beyond (1st ed., pp. 6-29). London: Routledge. https://doi.org/ 10.4324/9780429455308.

Law, J., Lindsay, G., Peacey, N., Gascoigne, M., Soloff, N., Radford, J., ... Band, S. (2002). Consultation as a model for providing speech and language therapy in schools: A panacea or one step too far? Child Language Teaching and Therapy, 18(2), 145-163. https://doi.org/10.1191/0265659002ct232oa

Law, J., Rush, R., Schoon, I., \& Parsons, S. (2009). Modeling developmental language difficulties from school entry into adulthood. Journal of Speech Language and Hearing Research, 52(6), 1401-1416. https://doi.org/10.1044/1092-4388(2009/08-0142)

Law, J., Roulstone, S., \& Lindsay, G. (2015). Integrating external evidence of intervention effectiveness with both practice and the parent perspective: The development of an interactive evidence database. Developmental Medicine and Child Neurology, 57(3), 223-228. https://doi.org/10.1111/dmcn.12630

Law, J., Levickis, P., Rodríguez-Ortiz, I. R., Matić, A., Lyons, R., Messarra, C., ... Stankova, M. (2019). Working with the parents and families of children with developmental language disorders: An international perspective. Journal of Communication Disorders, 82, Article 105922. https://doi.org/10.1016/j. jcomdis.2019.105922 
Law, J., McKean, C., Murphy, C.-A., \& Thordardottir, E. (2019). Managing children with developmental language disorder: Theory and practice across Europe and beyond (1st ed.). London: Routledge. https://doi.org/10.4324/9780429455308

Law, J., Roulstone, S., \& McCartney, E. (2019). National Vignettes: United Kingdom (2019). In J. Law, C. McKean, C. A. Murphy, \& E. Thordardottir (Eds.), Managing children with developmental language disorder: Theory and practice across Europe and beyond (1st ed., pp. 497-509). London: Routledge. https://doi.org/10.4324/ 9780429455308.

Law, J., Tulip, J., \& Beckermann, E. (2019). The development of the practitioner survey. In J. Law, C. McKean, C.-A. Murphy, \& E. Thordardottir (Eds.), Managing children with developmental language disorder: Theory and practice across Europe and beyond (1st ed., pp. 30-55). London: Routledge. https://doi.org/10.4324/ 9780429455308.

Liu, X. (2003). Policy tools for allocative efficiency of health services / Xingzhu Liu. World Health Organization. https://apps.who.int/iris/handle/10665/42787.

Lowe, H. (2018). The effectiveness of classroom vocabulary intervention for adolescents with language disorder. Unpublished Doctoral thesis. City: University of London.

McKean, C., Law, J., Laing, K., Cockerill, M., Allon-Smith, J., McCartney, E., ... Forbes, J. (2017). A qualitative case study in the social capital of co-professional collaborative co-practice for children with speech, language and communication needs. International Journal of Language \& Communication Disorders, 52 , $514-527$. https://doi.org/10.1111/1460-6984.12296

McKean, C., Gerrits, E., Tulip, J., \& Tolonen, A. K. (2019). Service delivery for children with language disorders across Europe and beyond. In J. Law, C. McKean, C. A. Murphy, \& E. Thordardottir (Eds.), Managing children with developmental language disorder: Theory and practice across Europe and beyond (1st ed., pp. 84-109). London: Routledge. https://doi.org/10.4324/9780429455308.

Mecrow, C., Beckwith, J., \& Klee, T. (2010). An exploratory trial of the effectiveness of an enhanced consultative approach to delivering speech and language intervention in schools. International Journal of Language \& Communication Disorders, 45(3), 354-367. https://doi.org/10.3109/13682820903040268

Meekinson, W. G., Mackenzie, C. J. G., \& Fraser, B. (1975). Critical requirements in regional health planning. Canadian Journal of Public Health / Revue Canadienne de Sante'e Publique, 66(4), 299-306. http://www.jstor.org/stable/41987471.

Messarra, C., \& Kouba Hreich, E. (2019). National Vignettes: Lebanon (2019). In J. Law, C. McKean, C. A. Murphy, \& E. Thordardottir (Eds.), Managing children with developmental language disorder: Theory and practice across Europe and beyond (1st ed., pp. 310-324). London: Routledge. https://doi.org/10.4324/ 9780429455308.

Michie, S., van Stralen, M. M., \& West, R. (2011). The behaviour change wheel: A new method for characterising and designing behaviour change interventions. Implementation Science, 6(42). https://doi.org/10.1186/1748-5908-6-42

Ministry of Employment. (2021). Bekendtgørelse af lov om ret til orlov og dagpenge ved barsel (barselsloven) (Accessed 23 March, 2021) https://www.retsinformation.dk/ eli/lta/2021/235.

Morel, S. (2012). La cause de mon enfant: Mobilisations individuelles de parents d'enfants en échec scolaire précoce. Politix, 99, 153-176. https://doi.org/10.3917/ pox.099.0153

Norbury, C. F., Gooch, D., Wray, C., Baird, G., Charman, T., Simonoff, E., ... Pickle, A. (2016). The impact of nonverbal ability on prevalence and clinical presentation of language disorder: Evidence from a population study. Journal of Child Psychology and Psychiatry, 57(11), 1247-1257. https://doi.org/10.1111/jcpp.12573

O'Connor, S., \& Pettigrew, C. M. (2009). The barriers perceived to prevent the successful implementation of evidence-based practice by speech and language therapists. International Journal of Language \& Communication Disorders, 44(6), 1018-1035. https://doi.org/10.1080/13682820802585967

Oosthuizen, H., \& Southwood, F. (2019). National Vignettes: South Africa. In J. Law, C. McKean, C. A. Murphy, \& E. Thordardottir (Eds.), Managing children with developmental language disorder: Theory and practice across Europe and beyond (1st ed., pp. 441-450). London: Routledge. https://doi.org/10.4324/ 9780429455308.

Pence, K. L., Justice, L. M., \& Wiggins, A. K. (2008). Preschool teachers' fidelity in implementing a comprehensive language-rich curriculum. Language, Speech, and Hearing Services in Schools, 39(3), 329-341. https://doi.org/10.1044/0161-1461(2008/031)

Pérez-Llantada, C. (2012). Scientific discourse and the rhetoric of globalization: The impact of culture and language. London: Continuum International Publishing.

Poland. Ministry of National Education. (2017). Rozporzadzenie Ministra Edukacji Narodowej z dnia 24 sierpnia 2017 r. w sprawie organizowania wczesnego wspomagania rozwoju mowy. Warsaw: Prime Minister of Poland (Dz.U. 2017 poz. 1635).

Roberts, M. Y., \& Kaiser, A. P. (2011). The effectiveness of parent-implemented language interventions: A meta-analysis. American Journal of Speech-language Pathology, 20(3), 180-199. https://doi.org/10.1044/1058-0360(2011/10-0055)

Rodríguez-Ortiz, I. R., Acosta-Rodriguez, V. M., Nieva, S., \& Saldaña, D. (2019). National Vignettes: Spain. In J. Law, C. McKean, C. A. Murphy, \& E. Thordardottir (Eds.), Managing children with developmental language disorder: Theory and practice across Europe and beyond (1st ed., pp. 451-459). London: Routledge. https://doi. org/10.4324/9780429455308.

Sapir, A. (2006). Globalization and the reform of European social models. Journal of Common Market Studies, 44(2), 369-390. https://doi.org/10.1111/j.14685965.2006.00627.x

Schooling, T., Venediktov, R., \& Leech, H. (2010). Evidence-based systematic review: Effects of service delivery on the speech and language skills of children from birth to 5 years of age (pp. 1-230). Rockville MD: American Speech-Language-Hearing Association.

Serrano, A., Mas, J. M., \& Cañadas, M. (2016). Family systems and family-centred intervention practices in Portugal and Spain: Iberian reflections on early childhood intervention. In H. Sukkar, C. J. Duns, \& J. Kirkby (Eds.), Early childhood intervention: Working with families of young children with special needs (pp. 193-212). London: Routledge.

Singer, G. H., Agran, M., \& Spooner, F. (2017). Evidence-based and values-based practices for people with severe disabilities. Research and Practice for Persons with Severe Disabilities, 42(1), 62-72. https://doi.org/10.1177/1540796916684877

Stankova, M., Rodríguez-Ortiz, I. R., Matić, A., Levickis, P., Lyons, R., Messarra, C., ... Law, J. (2020). Cultural and Linguistic Practice with Children with Developmental Language Disorder: Findings from an International Practitioner Survey. Folia phoniatrica et logopaedica: official organ of the International Association of Logopedics and Phoniatrics (IALP), 1-13. Advance online publication https://doi.org/10.1159/000511903.

Topbas, S., Bulut, T., \& Gunhan, N. E. (2019). National Vignettes: Turkey (2019). In J. Law, C. McKean, C. A. Murphy, \& E. Thordardottir (Eds.), Managing children with developmental language disorder: Theory and practice across Europe and beyond (1st ed., pp. 485-496). Routledge: Abingdon-on-Thames. https://doi.org/10.4324/ 9780429455308.

Wake, M., Tobin, S., Girolametto, L., Ukoumunne, O. U., Gold, L., Levickis, P., ... Reilly, S. (2011). Outcomes of population based language promotion for slow to talk toddlers at ages 2 and 3 years: Let's learn Language cluster randomised controlled trial. BMJ, 343(7821), 1-10. https://doi.org/10.1136/bmj.d4741

Wales, D., Skinner, L., \& Hayman, M. (2017). The efficacy of telehealth-delivered speech and language intervention for primary school-age children: A systematic review. International Journal of Telerehabilitation, 9(1), 55-70. https://doi.org/10.5195/ijt.2017.6219

Watts Pappas, N., McAllister, L., \& McLeod, S. (2016). Parental beliefs and experiences regarding involvement in intervention for their child with speech sound disorder. Child Language Teaching and Therapy, 32(2), 223-239. https://doi.org/10.1177/0265659015615925

WHO. (2001). International classification of functioning, disability and health. Retrieved July 1st, 2020 ICF https://apps.who.int/iris/bitstream/handle/10665/42407/ 9241545429.pdf.

Zegan, G., Totolan, E. G., \& Ene, C. (2019). National Vignettes: Romania. In J. Law, C. McKean, C. A. Murphy, \& E. Thordardottir (Eds.), Managing children with developmental language disorder: Theory and practice across Europe and beyond (1st ed., pp. 387-397). London: Routledge. https://doi.org/10.4324/ 9780429455308. 